\section{Bioethics, culture and infanticide in Brazilian indigenous communities: the Zuruahá case}

\author{
Bioética, cultura e infanticídio em comunidades \\ indígenas brasileiras: o caso Zuruahá
}

${ }^{1}$ Cátedra UNESCO de Bioética, Universidade de Brasília, Brasília, Brasil. 2 Programa de Pós-graduação em Bioética, Universidade de Brasília, Brasília, Brasil.

Correspondence

V. Garrafa

Programa de Pós-graduação

em Bioética, Universidade

de Brasília.

C. P. 04367, Brasília, DF

70904-970, Brasil.

volnei@unb.br

\author{
Saulo Ferreira Feitosa 1 \\ Volnei Garrafa 1,2 \\ Gabriele Cornelli 1,2 \\ Carla Tardivo 1 \\ Samuel José de Carvalho ${ }^{1}$
}

\section{Introduction}

There is a very wide diversity of Indian peoples in Brazil. According to data from the Brazilian Institute for Geography and Statistics (IBGE. 2000 census. http://www.ibge.gov.br), it is estimated that there are around 240 ethnic groups within the country, with a population of 734,131 individuals. Although five centuries have passed since the arrival of the first colonizers to what now constitutes Brazil, there are many tribal groups that live with minimal contact outside the group, or even in complete isolation. These groups maintain very little or no relationship with Brazilian national society.

Different traditional practices are part of the indigenous cultural diversity that is present in Brazil. Among these, the practice of "infanticide" has been under the spotlight as part of the national debate about bioethics. At the end of 2005, the Evangelical Parliamentary Front, a cross-party political lobby group, raised the topic at the Brazilian National Congress, through a public hearing session that resulted in the launching of the National Campaign in Favor of Life and Against Infanticide.

Infanticide; Bioethics; Indigenous Population 


\section{Infanticide in indigenous cultures}

\section{The various motives}

Throughout the history of the colonization of the Americas, there are records of the practice of infanticide among indigenous peoples. In Spanish America, and particularly in Mexico, human sacrifice as performed by the Aztecs was heavily criticized by intellectuals in the Spanish Court. Prominent among these intellectuals was Ginés de Sepúlveda, a chronicler for the Emperor of Spain. He abhorred the practice and defined it as an act of savagery and inhumanity, thereby attributing to the Indians a degree of inferiority. However, even in those days, there were those who sought to understand moralities that differed from their own. Thus, Bartolomeu de Las Casas, the bishop of the diocese of Chiapas, confronted Sepúlveda during an historical debate in Valladolid, in 1550. He took the stance of defending the Indians and indicated that human sacrifice was itself accepted within Christian religious beliefs, as shown in some books of the Bible 1 .

Infanticide has often been identified with sacrificial rites, as in the biblical episode in which God asks Abraham to sacrifice Isaac, his only son. Nevertheless, in some cultures, it has always functioned as a means of birth control and even as a mechanism for adapting human life to adverse conditions of survival in certain hostile environments, especially under jungle conditions. In Brazil, it continues to be practiced among some indigenous communities for several reasons. For practical purposes these reasons can be grouped into three general criteria: the mother's inability to devote the care and attention required for yet another child; the newborn's capacity or incapacity to survive within the physical and socio-cultural environment into which he or she was born; and the preference for one sex over the other.

In the first case, care is taken by the mothers to avoid twin births or births within short spaces of time, since they would have difficulty in carrying out their daily tasks inside and outside their home while at the same time taking care of the children. For many indigenous peoples, mothers do not become pregnant while they are still breastfeeding. For this reason, there is usually an interval of at least two years between births. If a new pregnancy occurs earlier than expected, the mother may decide that the newborn has to die.

The second situation takes into consideration limitations of a physical, mental and/or religious nature. Included in this criteria are the following cases: newborns presenting physical deficiencies or retarded psychomotor develop- ment; situations in which the mother dies during or just after delivery; children who do not have a social father; children who are born from a father from another tribe, and so on. Included in this criteria are cases of abnormalities that would not apparently justify sacrificing the child, such as albinism. Albino children must take great care to avoid exposure to the sun, and living in indigenous communities without being exposed to the sun would be all but impossible: in such communities, lodgings are very open and sunlight penetrates easily, and people do not stay inside for long periods of time, because they see the earth, this "big house" that has the sky as its roof and is lit naturally by the sun, as their natural habitat. It is therefore extremely rare to find cases of albinos among Indians. Survival difficulties and fears about the color of albinos (which are generally considered to be associated with evil), cause them to be sacrificed.

The third criteria used in this classification relates to sex-determined infanticide. Press reports generally state that male newborns are given preference. Although this does occur in some cases when the first child is expected to be male, it is not always female children that are sacrificed. Among the Waiwái, for example, sex determination is only adopted as a criteria when a newborn child is the same sex as their four older siblings, independently of which sex this may be 2 .

\section{Birth and the cultural construction of the human body}

During a seminar on Legal Pluralism held at the Graduate School of the Federal Union Prosecution Office (ESMPU) in 2005, a federal attorney acting in the State of Roraima, Brazil, asked the foreign representative of the International Labor Organization (ILO) about how to proceed in relation to cases of infanticide among the indigenous Yanomami people. The ILO representative replied that the universal nature of human rights should be respected. Intervening in the debate, the anthropologist Ivan Soares, of the Brazilian Federal Prosecution Office (MPF), disagreed. Speaking from his experience among the Yanomámi, he emphasized that Yanomámi women had full autonomy to decide whether their children should live or not. The mother withdraws into the forest to give birth and if she does not welcome the child into her arms, it is as if the child had never been born. Thus, it is interpreted that, in that culture, there is also a "post-delivery birth", in other words an act of being "culturally born": when the mother does not welcome the newborn, she does not touch it and abandons it in the forest. In this way, the child is not born into the community. 
According to many indigenous peoples, the human body is the result of a cultural "construction". This is a complete process that stretches from birth to puberty, during which time the body receives the marks of the culture and goes on being culturally constructed: "The human being under construction is 'naked' and does not use paint or adornment" 3 (p. 35). From this perspective, it can be assumed that in the beginning, there is a non-human body or at least one that is not completely humanized, and it becomes human through the "construction" rites for the body. The person is also the result of a cultural construction. The concepts of body and person are demonstrated very well in the following transcript: "The expression 'I am making' [my son] is used by the Yawalapiti people to explain the actions of a man in certain contexts that are crucial for producing new identities: (a) during the period in which the man constructs the body of the child in the mother's body by means of repeated sexual intercourse; (b) during the period of reclusion at the time of puberty, especially at its outset, when the parents must abstain from sex, administer emetics to the recluse and care for his needs..." 3 (p. 33).

Acquiring an understanding of the place and role of the body within indigenous cultures, as well as their notion of person, is an essential precondition for understanding the significance and implications of infanticide within these cultures. The individual is produced physically with a defined and equally produced social purpose. Corporality is understood within a broad perspective of constructing persons: men and women who are socially acceptable and justifiable.

\section{The Zuruahá people}

\section{The history of contact}

The Zuruahá people maintained cautious isolation until 1980, when they were located by a pastoral religious team dedicated to indigenous people in the municipality of Lábrea, in the Amazon region. This team belonged to the Missionary Council for Indigenous Peoples (CIMI), a body within the Brazilian National Bishops' Congress (CNBB), that had been alerted to the existence of the Zuruahá through news of their conflicts with groups exploiting natural resources of the region. Almost three decades since initial contacts, they continue to live in isolation and have little contact with Brazilian national society. They speak a language belonging to the Arawá family and have methods of social organization that meet their own needs.
Their geographic location is in the municipality of Tapauá, in the State of Amazonas, at a distance of $1,228 \mathrm{~km}$ from Manaus along the rivers. Difficulties of access have helped them to maintain a certain degree of control over their traditional territory. This has prevented invasions by people interested in exploiting the natural wealth existing within their lands. By preventing invasion, they have also avoided intense contact with foreign cultures, thus ensuring that their cultural mechanisms have been maintained undisturbed. Kroemer ${ }^{4}$ (p. 35), in relating his experiences with the Zuruahá people, argued that: "All Zuruahá people usually live in a single house, a longhouse settlement called an oda, in which as members of the same people, they recognized the same criteria for social relationships, the same cultural patterns of life and the same ways of interpreting their activities through their religious world".

Soon after making contact with the Zuruahá people, the CIMI team realized that they were a tribal group capable of assuring their own selfsustainability and of keeping their culture alive, provided that they remained free from invaders. For this reason, CIMI decided that an attitude of no direct interference with the life of the community should be adopted and that a commitment should be made to fight for the demarcation and protection of the Zuruahá territory. That in fact was achieved soon afterwards, when the National Indian Foundation (FUNAI) implemented this demarcation.

After the initial contacts, the team developed a model for remote follow-up, thus avoiding setting up a residential presence in the area and reducing the impact of interference with the group's life. The work of providing healthcare for the people in the community started, and a vaccination program was maintained to protect them from infectious-contagious diseases brought in by the white man's activities in extracting natural resources, while respecting the people's traditional medicine.

Four years later, another religious group, the JOCUM evangelical mission (Youths with a Mission), started to work among the Zuruahá people and decided to establish a permanent base in the area. Today, the people receive assistance from both missionary teams, which have different types of understandings of and interventions in the area.

The present population of the Zuruahá is 143 individuals. Data from the CIMI indicate that, between 2003 and 2005, there were 16 births, 23 deaths due to suicide, two cases of infanticide and one death by disease. On account of the high suicide rate, there was a $13 \%$ decrease in the 
population over this period. The mean age of the population in 2006 was 17.43 years; the percentage of the population above 30 years old was $16 \%$ and only $8.6 \%$ were over 40 years old; the male to female ratio was, respectively 1.12 to 0.88 .

\section{Infanticide and suicide in Zuruahá culture}

The high suicide rate mentioned above is an issue that has many correlations with infanticide, the primary interest of this paper. Although suicide is a phenomenon that is completely different to infanticide, given the assumption that an individual who committed suicide had the autonomy to do so, it is important to understand the relationship between infanticide and suicide within the cultural context of the Zuruahá people. Behind living or dying, there is an idea or conceptualization of what life or death is and whether or not it is worthwhile living.

Among the Zuruahá people, this conceptualization is very particular: "They conceive of human existence along two distinct paths: kunahã agi, the path of those who die by poisoning; and mazaruru agi, the path of those who die naturally" 4 (p. 150). Thus, death is the scope of existence. The consequences of this thinking are seen in numbers. Taking the reference point of the statistical data mentioned above, it can be inferred that "the principal factors relating to mortality among the Zuruahá are eminently social: $7.6 \%$ of all deaths are caused by infanticide and $57.6 \%$ by suicide" 5 (p. 99).

Even though death always has an impact because it is a human phenomenon, in this environment it takes on a shape that differs from death in other cultures. It makes sense to live if life is good and peaceful, without excessive suffering for the individual and for the community. Thus, if a child is born with physical defects or without a father to protect it, there is no reason to live because life would be excessively heavy for this child, for its family and for its people.

In dealing with the topic of infanticide, Kroemer 4 reported that newborn girls from a single mother are expected to be killed. Thus, while still with the placenta, the child is left in the thickets or in a basket until the mother herself or some relative kills it. This rejection of a newborn girl without a recognized father is, above all, a response to the cultural patterns of social relationships, in which it is inconceivable for a child without a father to become a new member of that society. However, when a boy without a father is born, society imposes on him a lower status in relation to other boys. His life may be maintained solely because of the usefulness of men for society.
Nevertheless, there are reports of situations in which a mother who is prepared to take on the task of bringing up a daughter that will not be recognized socially by the community accepts the newborn outside of the longhouse. There was a case of a widow who brought up two children that, according to the community, should have been killed because they were the daughters of a single mother. Years later, both of them committed suicide: one did it just after getting married and the other followed her, in a suicide pact 4 . This example shows a certain relationship between infanticide and suicide that is not inherent to these phenomena but results from a historical process and from a specific sociocultural environment. Suicide among the Zuruahá involves historical and religious characteristics and even social tensions and crises. It is seen as a form of human existence, such that only through death is it possible to attain true existence: “The Indians say that human existence only makes sense if its aim is suicide. Their guidelines for understanding life indicate that suicide is the highest of all values. The philosophy of the Zuruahá says that there are only two paths for human existence: the first, via suicide by poisoning, called kunaha, which leads to heaven for those who take the poison (...). Their rites, chants and prayers relate to and are aimed towards this true existence. The second path leads to death through old age; this is a path that today is considered arduous..." 4 (p. 78).

Given this understanding of human life, waiting to grow old is not synonymous with wisdom. For this reason, in this culture, old people do not have the status of venerable wise men, as is commonly seen among other indigenous peoples. Here, they are called hosa, a word that means "useless" or "spent". Moreover, most of them have already made attempts to commit suicide. To avoid a future of pain and disrespect in old age, children start from an early age to live with the possibility of committing suicide. In their games, boys and girls act out how they will die and what their funeral rite will be like. They all know about how to use timbó, a species of liana that contains a deadly poison. Using it is an act of courage. For this reason, "parents live with the conviction that one day their children will drink poison" 4 (p. 78).

Kroemer 4 concluded from his analysis that the practice of suicide among the Zuruahá was the consequence of a violent massacre that they had suffered around a century before contact made by the CIMI team. The survivors developed a psychiatric disease that he named "ethno-trauma". At that time, all the shamans were killed, together with most members of the tribe. Those who managed to avoid being killed in the massacre died as a result of colds and measles epidemics. 
The people responsible for this destruction were rubber extraction pioneers in the Brazilian Amazon region at the end of the nineteenth century.

\section{The case of the two children}

\section{Two cases of infanticide avoided}

In March 2005, two Zuruahá children were removed from the settlement by members of JOCUM, in an attempt to avoid their deaths. Together with them, another six people left the community, including their mothers. They stayed for some time at JOCUM's premises in the city of Porto Velho, capital of the State of Rondônia, in the Amazon region, and then went to São Paulo.

The two children are girls, one who presents features akin to pseudo-hermaphroditism and the other, delayed psychomotor development, possibly due to cerebral palsy. Both girls' diagnoses were made at the Hospital das Clínicas, University of São Paulo. At that time, the first one was two years old and the second was one year and five months. They will be referred to by the pseudonyms of Mãy e Yatakaminá, respectively, to protect their identities.

After Mãy had been identified as female, she underwent a surgery and was returned to her settlement. Since she requires continuing medication, she is receiving assistance from agents of the National Health Foundation (FUNASA), a body concerned with indigenous health issues and housed within the Brazilian Ministry of Health. Her father is responsible for the treatment and she needs to go to Manaus every three months for a clinical review. Because Yatakaminá needs specialized multidisciplinary child rehabilitation treatment, she is receiving care at Hospital Sarah Kubitschek, in Brasília, which specializes in diseases of the locomotor system.

From information provided by the CIMI team working in the area, the community did not reject Mãy upon her return. Her parents are managing to keep up the required care, although they refuse to travel to Manaus every 90 days. With regard to Yatakaminá, the community's expectation is that, when she returns, she will have acquired the motor skills to allow her to walk.

The peculiarity of the two cases lies in the fact that the abnormalities were not easy to identify just after birth. Perhaps the late perception of the physical problems made it possible for them to survive. However, the sociocultural reality of the group to which they belong does not ensure that they will be definitively accepted as members of the community. As described earlier, among the Zuruahá, life and death are intermingled in the way that are valued. In the last suicide pact that took place, in July 2006, all the brothers of Mãy's father (i.e. her paternal uncles) committed suicide. Out of her family, her father is the only survivor.

\section{The public hearing at the Brazilian} National Congress

The case was discussed at a public hearing at the National Congress on December 14, 2005, called by the Commission for the Amazon Region, National Integration and Regional Development. The declared aim of the hearing was "to obtain clarifications regarding an accusation of unauthorized removal of children from an indigenous settlement". The congressmen responsible for requesting and holding the hearing were mostly members of the Evangelical Parliamentary Front, a group of congressmen that defend topics of interest to various evangelical churches, most of them Pentecostal. The hearing had been motivated by accusations published in the press that the children had been removed by missionaries from JOCUM without the knowledge of FUNAI and FUNASA, the official bodies of the Brazilian government.

The vice-president of FUNAI, the director of the Department of Indigenous Health of FUNASA and the national president and two missionaries from JOCUM took part as invited speakers in the debate.

As the debate developed, the discussion came to center on the issue of infanticide. The president of JOCUM, Bráulia Ribeiro, made it clear that in her understanding, the correct term to be used would be homicide: "The legal term... is homicide, because infanticide is when there is a problem with the mother. In this case, it is homicide. And we know that the custom of homicide is common among indigenous populations" 6 (p. 4). In making this affirmation, she referred to the Brazilian Penal Code, which defines the crime of infanticide as follows: Art. 123. To kill one's own child under puerperal influence, during delivery or immediately afterwards: Penalty - imprisonment of two to six years.

The representative from JOCUM was correct in the understanding that the prerequisite for "puerperal influence" defines the crime of infanticide. However, this condition is not necessarily identified in cases that occur among indigenous peoples. Among Indians, the decision to kill a child is not the mother's but, rather, it is a decision by the social and cultural group to which she belongs. For this reason, there are no records in the history of Brazil of the prosecution of indigenous women for this crime. 
Seeking to demonstrate that infanticide is not restricted to the Zuruahá, she made reference to other peoples, such as the Yanomámi: "There are various reports of homicide against indigenous children, caused by traditional cultural practices (...). Among the Yanomámi... one of the main concerns of the healthcare team is to reduce the number of cases of infanticide, which raised the coefficient of infant mortality from 39.56 to 121 per 1000 live births in the year 2003. In all, 68 children were victims of infanticide last year" 6 (p. 6).

She concluded her first intervention with the following affirmation: "Human beings have value because they are valuable. They have value because they exist. Their value isn't because they are Indian or because they are Brazilian. Life has more value than culture" 6 (p. 7).

The participating congressmen took up positions along the same lines. Congressman Afonso Henriques, a member of the Human Rights Committee of the Lower House based his position on the fifth article of the Federal Constitution of Brazil, which establishes the inviolability of the right to life. He advocated changes in indigenous cultures as a means of combating infanticide, starting always from values within the Christian faith. Other congressmen who were mostly also evangelical pastors, described encounters with some indigenous peoples and various experiences of evangelization that had changed these peoples' lives for the better.

The representative from FUNASA limited himself to discussing the removal of the children. On the other hand, the vice-president of FUNAI took up the debate and made some points about respect for the values of indigenous cultures and particularly those of the Zuruahá people, emphasizing their vulnerable condition: "The belief system of these Indians - and the anthropologists from JOCUM must know this - is closely bound up with the way their economy works and the basis of the social organization. (...) There is a striking inequality between the degree of complexity of our culture and the complexity of theirs, and between our aggressiveness in our ways of persuading people and working with them and the degree of fragility of their culture. There is no way they can resist the work of persuasion or catechism" 6 (p. 20)

In her response to this, the president of JOCUM advocated the creation of laws to criminalize the cultural practice of infanticide: "The same government that legislates to criminalize or sanction abuses committed by our Brazilian nature should also legislate to criminalize or sanction those committed by these cultures, because they are not less than us as people" 6 (p. 58).
From these discussions, two trends could be seen: the perspective of criminalizing the cultural practice of infanticide; and the need to intervene in indigenous cultures to convert them to the Christian faith and the values of Western civilization. The arguments exposed echoed the same refrain: life and the right to it are above culture. On the other hand, the representative from FUNAI highlighted the fragility of indigenous culture when exposed to confrontation with the dominant culture. It should be noted that, strangely, no space in the debate was given over to the correlated problem of suicide, the greatest cause of death among the Zuruahá.

The criminalization of a traditional cultural practice among indigenous people is no less than the application of the ancient decrees of the times of colonial and imperial Brazil to the present day. Both in Brazilian legislation and in international legislation, there have been many advances over the last three decades, towards recognizing the traditional rights of autochthonous peoples. In Latin America, there have been a growing number of discussions and experiences pointing towards legal pluralism, in which different rights are recognized. The conclusions from these discussions are that indigenous peoples possess their own rights. Moreover, since different rights are recognized, different forms of justice should also be recognized.

The participants in the debate cited on several occasions ILO Convention no. 169. This is an instrument recognized for its importance regarding the defense of indigenous rights and which has already been ratified as a law in Brazil. Nevertheless, they did not take into consideration what its eighth article establishes: "In applying national laws and regulations to these people, their customs or customary rights shall be taken into due consideration" 7.

A quick glance at history would seem to discredit altogether the idea that the imposition of the Christian faith is the solution for indigenous peoples. The history of Latin America is full of examples in which forced conversion to Christianity, instead of promoting life, contributed towards exterminating many peoples.

However, it could be seen that the public hearing discussed here took place among a limited group of interlocutors, almost all belonging to the same religious segment, and therefore they were not representative of Brazilian society. Most importantly, the hearing was unrepresentative because the party with greatest interest in it was absent: the Zuruahá. It must therefore be put on the record that, although the debate had been promoted within an appropriate space for exercising democracy, it took place without the par- 
ticipation of the protagonists and the different sectors concerned with the subject.

In May 2006, the same Evangelical Parliamentary Front launched its National Campaign in Favor of Life and Against Infanticide, with the aim of continuing the discussion on infanticide among indigenous communities.

\section{Discussing the morality of infanticide}

No matter how abominable infanticide may seem to some moral communities, it has a differentiated status and may constitute a social obligation [to others]. In this respect, Singer states that: "Infanticide has been practiced in societies that geographically stretch from Tahiti to Greenland, among a wide variety of cultures, ranging from nomadic Australian Aborigines to the sophisticated urban communities of ancient Greece or Mandarin China" 8 (p. 182).

In the case of the two Zuruahá girls, there was no doubt that both would be destined to die. Because the JOCUM missionaries knew the customs of the Zuruahá, they removed the girls from their environment, with the aim of avoiding their deaths. However, from the viewpoint of the Zuruahá, the fact that someone knew their customs could be sufficient reason for determining that the girls should not have been removed. According to Singer 8 (p. 182): "In some of these societies, infanticide was not only permitted but also, in certain circumstances, it was seen as a moral obligation. Failure to kill a sick or deformed baby was almost always seen as an error. Infanticide was perhaps the first type of population control, or the only means, in the case of many societies".

Reinforcing this line of reflection, Meggers 2 (p. 139) took the view that "the absence of any alternative to the mother's milk makes infanticide a humanitarian substitute for a slow death through hunger in situations in which the mother dies". Statements like this help in understanding the significance of infanticide in the Zuruahá culture. One such example could be the report of a case that occurred among the Zuruahá in 1987, in which Kroemer and Têre, missionaries from CIMI, not only witnessed but also attempted to prevent what in fact happened: "We had to do something, and Têre, with a mother's impulse, asked for the child. The Indians were unable to understand our attitude of wanting to save the child, which was subject to the ancient laws of the Zuruahá. Throughout the afternoon, we tried to convince the Indians to save the child. But we spoke from our own cultural world and expressed our feelings in favor of life against a universe that acted according to concepts of life and death different to our own. The values we understood and practiced were nullified: brought to nothing by other value models that governed and controlled the lives of the Zuruahá. There was no understanding on either side: each spoke in terms incomprehension of the other, the products of different cultural contexts" 4 (p. 67).

This report reveals an attempt at dialogue between moral positions foreign to each other that: “...did not share moral premises or rules of evidence and inference that were sufficient to resolve the moral controversies by means of a healthy rational argument, or that did not have a common commitment towards the individuals or institutions with the authority to resolve the controversies" 9 (p. 32).

Continuing with the report, Kroemer 4 describes how, unable to dissuade the community from its determination to rid itself of the unwanted child, he made an authoritarian intervention that he justified by the desperation he felt when he heard the baby crying, even taking the risk of suffering physical assault. But although he managed to get the child into his care, she died a few days later. This episode reveals that the case of Mãy and Yatakaminá was not the first attempt to intervene in this cultural practice. However, the lack of success in the first intervention may have softened the intensity of the impact it caused. On the other hand, if the child had survived, there would be no guarantee of a successful outcome. From this same community, there is a report of infanticide committed at a later stage, when the boy concerned had already reached the age of five. Thus, the ethics of a society is not only concerned with biological life but also, and especially, social life. Interventions such as the one described above have a high likelihood of resulting in the creation of a socially dead being.

The idea of a being that is socially dead favours an allusion to Giorgio Agamben's discussion on "life that does not deserve to be lived", in his work Homo Sacer: O Poder Soberano e a Vida Nua I ${ }^{10}$. The figure of the homo sacer, retrieved from ancient Roman law, embodies the prototype for social death. This individual could not be condemned to sacrifice, but was so despicable that anyone could kill him without suffering any penalty. The greatest punishment for this individual would be banishment, and there was no chance that a penalty would be dealt.

Beyond the philosophical discussion generated by the ambiguity of this legal figure, in which sacredness and "killability" reflect its ambivalence, it is important to reflect on the fact that biological birth does not necessarily signify life, or rather, it does not ensure cultural birth, that means, social life. Even if Kroemer and Têre had 
been successful in their attempt to save the biological life of the child, there would remain another task that is seemingly more difficult: to resuscitate the child, because it was born culturally dead. Saving the biological body without saving the cultural body is the same as condemning the individual to banishment, i.e. to the condition of social death.

There are in fact some reports on children in indigenous communities that were condemned to social death after escaping from infanticide. Among the Katukína people, one way of socially killing an individual is to withhold giving that person a name: "Some newborn children are named quickly, while others remain nameless even up [to] the age of two. The latter are undesirable children and nowadays, since infanticide is no longer practiced, failure to give the child a name has become a way of indirectly exposing that child to death" 11 (p. 10).

In consonance with this, Erikson 12 (p. 334) stated that "among the Matis, also in the State of Amazonas, Brazil, after naming the child, the possibility of infanticide is suspended".

This question of social life and death will be taken up again later.

\section{Abortion, infanticide and neonatal euthanasia}

The prevalence of infanticide in a wide variety of cultures across different locations suggests that it was formerly preferred to abortion. The latter is not only far from being an aseptic procedure but also puts the mother at risk of death and does not constitute an efficient birth control method because it is subject to failures. The importance given to infanticide over time has varied enormously. According to the status historically attained by human life and in particular by the newborn, infanticide was accepted without great concern during some historical periods, while at other times it merited great attention because it constituted serious disrespect for the morality in force at that time, thereby leading to rigorous punishment for those who committed that act.

In ancient Greece, abortion and infanticide were performed as birth control methods. As in Rome, they were not considered crimes, since the child only existed legally from the time it was accepted by the father. Although there was no absolute ethical condemnation of abortion, it was suggested to doctors that it should not be performed and that the practice of infanticide should be favored. Aristotle justified both practices for genetic and demographic reasons, as presented in Politika 13 (p. 150): "With regard to knowing which offspring should be abandoned or should be educated, there needs to be a law that prohibits the feeding of all deformed children. Regarding the number of offspring (since the number of births must always be restricted), if the customs do not allow abandonment and if certain matrimonies are so fecund that they go beyond the set birth limit, abortion needs to be provoked before the fetus acquires activity and life. In effect, it is only through activity and life that it will be possible to establish whether or not there has been a crime".

In the sixteenth century, when Europe had already adopted a moral position that was mostly against infanticide, the European colonizers and particularly the Portuguese were surprised to find, on arrival in the Eastern world, that this practice was accepted and frequently practiced. Nevertheless, some studies have indicated that infanticide was still recorded in Europe up to the end of the nineteenth century, occurring more among single women who were in a good financial situation.

In a study on birth control practices in Brazil during the first half of the twentieth century, Fabíola Rohden analyzed medical reports, police inquiries and legal cases during that period that involved cases of infanticide and abortion. She observed that "in some legal cases, the categories of infanticide and abortion even came to be used indiscriminately by police officers and judicial agents" 14 (p. 127).

With the appearance of effective contraception methods and women's appropriation of their reproductive rights, the general capacity of individuals to manage their sex lives has increased. This has resulted in a gradual decline in the number of cases of infanticide in Western society. At the same time, the struggle to decriminalize abortion has advanced. Today, in approximately three quarters of the countries in the world, abortion is not considered to be a crime, but infanticide is.

Thus, a certain bioethical relationship between abortion and infanticide can be outlined. In this light, Singer 8 (p. 198) overcame the distinction between the moral acceptability of abortion and the unacceptability of infanticide: "Birth does not signal a morally significant dividing line. I do not see how it is possible to defend the point of view that fetuses can be 'substituted' before birth but newborns cannot be. Nor is there any other characteristic, for example viability, that could perpetuate the division between the fetus and the baby".

Tooley 15, in his Abortion and Infanticide, suggested that people who accept abortion find themselves obliged, for the sake of coherence, to accept infanticide. Likewise, he said, people who do not accept infanticide are also obliged not to 
accept abortion. The argument is evident: from a biological point of view, human life is not in itself a right. Nothing like a natural right to survival can be envisaged. The individual's survival is in fact just one of the possibilities: this applies to all forms of life, including animals that are considered to be "higher". Thus, especially among humans, the neoteny that characterizes them, i.e. the newborn's severe incapacity to provide for itself, obliges the community to take care of the newborn so it can survive. Thus, the right to life is something that society determines. It is a social right that defines that a certain individual of the species that has been born or is to be born will receive the right to life, i.e. will be welcomed to live within the community.

Abortion and infanticide end up being equivalent to each other, since they are results from a decision by the community not to give the right to life, either to a fetus or to a newborn, for a wide diversity of ethical reasons within the society in question. The right to life, in relation to both abortion and infanticide, is a social right.

The following two examples will show how this conceptualization has emerged.

In the year 1986, through a decision that became known as the Bowen vs. American Hospital Association ruling, the United States judiciary accepted that "a newborn that suffers from mental retardation or physical deformity may be 'denied assistance, provided that this is with the parents' consent, even if this denial of assistance leads to its death. Feeding is considered to be a form of assistance" 16.

More recently, the EFE news agency 17 released the news on November 12, 2006, that the "Anglican church accepts euthanasia for severely ill babies". This position adopted by the Anglicans became public through a communication to the British press. According to EFE, the Anglicans presented humanitarian and economic reasons to justify their decision. In light of the suffering of such babies and the accompanying high public healthcare costs, when resources invested there could save other lives, suspension of medical assistance would become acceptable. Referring to declarations by the Anglican bishop Tom Butler, the agency stated that, in his view, "there may be occasions when Christian compassion overlies the rule of preservation of life at all costs" and that one example of this was "disproportionate treatment just to prolong a life" 17.

Both the court decision in the United States and the recommendation by the Anglican church make neonatal euthanasia possible, resembling a form of infanticide and, more precisely, a form resulting from not providing assistance to the baby. They emphasize that neonatal euthanasia is justified if the newborn is incapable of survival. Among indigenous communities too, the criteria of being incapable of survival is considered to be the determining factor for making the decision on infanticide. The difference lies in cultural conditions and possibilities of and existing resources. What is not viable in one set of circumstances may be the opposite in another. The concept of being incapable of survival is also a culturally measured concept.

Thus, the categories of abortion, infanticide and neonatal euthanasia can be understood to be very close to each other. The choice between them is essentially determined by factors of a cultural, economic and legal nature and by the moral community that has to make the decision.

\section{Possibilities for intervention}

The capacity to dialogue with other, different peoples is a premise for enabling bioethical action. The reflection of a lay bioethical approach is thus marked out by taking the plurality and diversity of the collective and individual social players into consideration in each given context. In particular, with regard to Intervention Bioethics, the theoretical line of bioethical thinking that was developed some years ago in Brazil, the practice of establishing dialogue is proposed as a means for transformation and inclusion. In this practice reflections result in concrete actions and attitudes that promote justice, coresponsibility and solidarity. For this reason, this theory is understood to be adequate to deal with the discussion on infanticide among indigenous communities. Although this issue is among the bioethical dilemmas of situations that can be called "persistent", because of its historical nature, it is equally within the field of "emerging situations", insofar as the debate on this issue is showing up again on the agenda at this point in the development of humanity, at the start of the twenty-first century 18 .

Independent of whether or not the indigenous peoples maintain contact with Brazilian national society, they do have nor exercise moral values recognized by their own "legal system". This means that, even if they live in association with national political institutions, they practice indigenous law in parallel to Brazilian law. In this light, and from the viewpoint of bioethical analysis, one must ask what would be the meaning of an intervention aimed at abolishing the practice of infanticide, considered as a crime by national legislation.

Intervention Bioethics takes human rights as its reference point. From October 2005 onwards, 
when UNESCO's Universal Declaration on Bioethics and Human Rights was adopted by 191 countries by consensus, the question of human rights was converted into a bioethical reference point of a universal nature. Since infanticide is considered to be a crime against human rights, it could be supposed at first sight that it is imperative to be against it, independently of any cultural conditions. However, acting in this way would bring the risk of imposing imperialistic and centralist logic under the pretext of ethics and law.

We are faced with a situation in which both the general and the particular need be considered. It is the classical debate between universalism and cultural relativism. Thus, on the one hand, the anthropologist Roberto Cardoso de Oliveira 19 (p. 183-4) in reflecting on this topic stated that: "While the moral rules within the microsphere have a particular nature and can always be observed in the most intimate instances (like those regulating sex life, for example), the vital interests of humanity are to be found in the macrosphere, and the moral rules that incorporate these interests gain a universal dimension (like those regulating human rights, for example)".

On the other hand, dealing with the applicability of the Universal Declaration of Human Rights to indigenous cultures, another anthropologist, Alcida Rita Ramos, took the view that "To condemn infanticide, as practiced in some indigenous societies, because it is contrary to the third article of the Declaration of the Rights of Man - 'Every man has the right to life, liberty and personal security' - would be to judge others by Western values" 20 (p. 7).

The discussion therefore goes beyond the theoretical and political limits of universality or ethnicity as places for defining fundamental human rights. However, the affirmation of the difference cannot in any way dispense with the need for dialogue.

Habermas 21 sought discursive ethics that could be justified around the world and indicated communication communities as a means for making this dialogue possible. He established that the initial condition for validating the discussions would be the competence of the communication among the people involved in the dialogue. For this, "all the participants in a discussion must have the same opportunity to undertake acts within communicative speech: initiating, intervening, interrogating and responding" 21 (p. 153).

Nonetheless, the form of a dialogue like this one about infanticide, needs above all to be fair. In a proposal for intercultural dialogue between political agents belonging to Western society and political agents from indigenous societies, there will always be present a power relationship, derived from the reality of dominance of one culture over the other, established since the outset of the process of European colonization. This was well recalled in the words of the vice-president of FUNAI mentioned earlier, regarding the fragility of indigenous culture in the face of attempted persuasion. It thus becomes a challenge to establish a dialogue that is real and not a mere disguise for yet another authoritarian imposition of Western morality.

A process of dialogue needs to be developed in which the knowledge ecology can be experienced 22. Because this approach considers incompleteness to be inherent to all knowledge, it reduces the risks of pseudo-dialogue. Olivé 23 (p. 129) took a position along the same lines: "Different groups of human beings may arrive at different bodies of beliefs about the world that allow them to act appropriately within their environment, and there is no absolute set of criteria or principles that makes it possible to settle the question of which of these different beliefs is correct, the only correct one".

Intervention Bioethics actions have the purpose of enabling authentic dialogue, thus placing such beliefs in a morally and ideologically defined position: "This theoretical proposal offers a concrete alliance with the more fragile side of society, including a new look at different dilemmas, among which: autonomy versus justice/equity, individual benefits versus collective benefits, individualism versus solidarity; superficial changes versus concrete and permanent transformations; neutrality towards conflicts versus politicization of conflicts" 18 (p. 401).

Choosing to establish an alliance with the more fragile elements of society is an essential precondition for establishing the basis for developing the process of dialogue. A priori, the intention not to impose a unilateral decision is put forward. Nevertheless, this assumption will not in itself ensure the fair conditions for the dialogue. Because bioethics practitioners are themselves members of a part of Western society, they are not neutral. They carry the mark of the traumatic inheritance left behind by the conquest and by the heavy history of dominance.

Therefore, some criteria of fairness in the dialogue must be observed to function as precautionary principles, thus seeking to avoid the risk that authoritarian practices might again come into use. First of all, respect for otherness needs to be ensured and the sole purpose of the whole dialogue has to be the community's welfare. In this respect, any agency that might have particular interests, whether of a political, religious or 
economic nature, will already be compromising its impartiality in the process. Secondly, it is essential to have the deepest possible knowledege regarding the culture of the people with whom the dialogue will be established. Prior manifestation of interest in establishing this dialogue expressed by members of the community is still needed. Without at least respect for these criteria, dialogue will be an imposition and the ethical debate will give way to the violence of the law of the strongest.

In recent Brazilian history there is an example of an indigenous group who abandoned the practice of infanticide, following what can be considered to be the first experiment of such a dialogue. This was the case of the Tapirapé people, located in the State of Mato Grosso, whose abandoning of the practice seems to have occurred without trauma. In 1952, a team of nuns from the congregation of the Little Sisters of Jesus went to live among the Tapirapé people. At that time, the population consisted of 47 individuals. The nuns were followers of Charles de Foucauld, and they proposed to live together among the community without any intention to carry out catechism activities. They therefore adopted the perspective of a "silent mission". Living continuously with the people of the community, they identified the existence of rigorous family planning, guided by birth control through infanticide. The nuns started to be concerned about the possibility that the group might become extinct and, little by little, conditions were created for discussing this risk with the community.

However, the discussion only became possible after the Tapirapé people identified the missionaries as their allies in the struggle against oppression caused by segments of the society to which the nuns themselves belonged. Thus, infanticide came to be discussed within an agenda that also included other topics of importance to the people: demarcation of their lands, expulsion of invaders from their territory, attention to individuals' health, etc. There was logic to this, since an increase in population depended on ensuring conditions of survival for everyone. At the time, the community faced serious problems resulting from persecution and invasion of their lands. After some time, the Tapirapé people managed to demarcate their traditional territory, the practice of infanticide was abandoned and the population started to grow (although not necessarily in that order). Today, there are around 500 people and the Little Sisters remain with them. In the anthropological literature, this case has become recognized as an experience of successful intervention.
The apparent success of this experience leads to the belief that similar processes might possibly occur among other peoples. There are even reports of isolated experiences in which certain individuals in indigenous communities decided not to sacrifice their children. Among the Zuruahá people, some individual attempts that did not work out have been reported, but there is information from other peoples that, although they may represent exceptions, can point towards greater success.

In July 2005, technical experts from the Brazilian Agricultural and Livestock Research Company (EMBRAPA) and FUNASA drew up a technical communication on albinism among indigenous communities. They highlighted the case of an albino girl of the Kuikúru people, in the Xingu Indigenous Reserve. When they met her, she was at the start of puberty and had escaped sacrifice because she was the couple's first daughter. When she was born, her parents thought that she might change color with the passage of time. Their other three children born subsequently with the same anomaly were sacrificed. The survivor's skin presented recurrent wounds. She suffered discrimination and would certainly have difficulty in achieving marriage 24 . It can be noted that, even after discovering later on that their first child would not change color, her parents did not sacrifice her. The authors of the technical report stated that the girl was in reclusion when they arrived there. Reclusion is a form of social and cultural inclusion: through this process, the teenagers prepared for adult life. Thus, even though she was suffering some kind of prejudice, the community was showing that it was overcoming other types of prejudice: in this specific case, by including an albino girl into society.

\section{Conclusion}

Going beyond the positive assessments of the anthropological literature, we can in fact consider that, from a strictly bioethical point of view, the intervention of the Little Sisters was an experience of relatively successful bioethical dialogue, at least for the following reasons:

The Little Sisters took a stance of non-authoritarian dialogue with the indigenous community that started from living in association with and acquiring profound knowledge of the other people's culture and ethics.

The discussion on infanticide was undertaken within the broader context of defining strategies aimed at enabling the survival of a community threatened with extinction. 
Nevertheless, from the point of view of interventionist bioethics, it would not at any time be correct to consider abandonment of the practice of infanticide per se as a success. In this case, success would be measured in terms of achieving a dialogue between morals foreign to each other, under conditions of profound respect for the other people's culture and, in particular, under conditions of protecting the vulnerable indigenous culture from the pressure of the dominant culture.

In theory, therefore, a dialogue established with great care, between the ethics of Western culture that is today mostly contrary to infanticide, and the ethics of the Zuruahá people, could result in a better understanding among the westerners, of the particular reasons for the practice of infanticide and the nature of its ethics within these people's reference ethical system.

From a perspective of intervention and dialogue, it can in no way be considered bioethically acceptable to attempt to impose a standpoint on the Zuruahá people regarding infanticide, such as the Christian religious view that motivated the consequent removal from the community of individuals socially marked out to die. It is likewise unacceptable any attempt to criminalize the practice of infanticide within that cultural context.

\section{Resumo}

O artigo analisa a prática do infanticídio em comunidades indígenas brasileiras. Tomando como referência um caso específico envolvendo duas crianças do povo Zuruahá, focaliza o tema sob uma abordagem mais abrangente e discute como o infanticídio é interpretado em outros povos indígenas. Foram considerados, na discussão, os debates ocorridos durante a Audiência Pública realizada no Congresso Nacional Brasileiro, em dezembro de 2005, que analisou o tema, além de revisão bibliográfica. Diante dos posicionamentos assumidos naquela audiência, procurou-se identificar os problemas éticos e os dilemas morais, contextualizando-os e analisando-os à luz do respeito ao pluralismo cultural. A fim de contribuir com o debate, os autores analisam as possibilidades de intervenção nas práticas tradicionais de infanticídio, recusando qualquer opção que não esteja ancorada numa atitude de profundo respeito pela cultura de outros povos ou que não apresente condição de dialogar com indivíduos ou grupos com diferentes moralidades.

Infanticídio; Bioética; População Indígena

\section{Contributors}

S. F. Feitosa, V. Garrafa and G. Cornelli worked on all phases of the manuscript. C. Tardivo and S. J. Carvalho worked on the literature review and the revision of the text. 


\section{References}

1. Todorov T. A conquista da América: a questão do outro. São Paulo: Editora Martins Fontes; 1983.

2. Meggers BJ. Amazônia: a ilusão de um paraíso. Rio de Janeiro: Editora Civilização Brasileira; 1977.

3. Castro EBV. A fabricação do corpo na sociedade Xinguana. In: Oliveira JP, organizador. Sociedades indígenas e indigenismo no Brasil. Rio de Janeiro: Editora Marco Zero; 1987. p. 31-41.

4. Kroemer G. O povo do veneno. Belém: Edições Mensageiro; 1994.

5. Dal Poz J. Crônica de uma morte anunciada: do suicídio entre os Sorowaha. Rev Antropol (São Paulo) 2000; 43:89-144.

6. Núcleo de Redação Final em Comissões, Departamento de Taquigrafia, Revisão e Redação, Câmara dos Deputados. Comissão da Amazônia, Integração Nacional e Desenvolvimento Regional: audiência pública no. 2096/05. Brasília: Câmara dos Deputados; 2005.

7. Decreto $\mathrm{n}^{\circ}$. 5.501, de 19 de abril de 2004. Promulga a Convenção no ${ }^{\circ} 169$ da Organização Internacional do Trabalho - OIT sobre povos indígenas e tribais. Diário Oficial da União 2004; 20 abr.

8. Singer P. Ética prática. São Paulo: Editora Martins Fontes; 2002.

9. Engelhardt Jr. HT. Fundamentos da bioética. São Paulo: Edições Loyola; 1998.

10. Agamben G. Homo sacer: o poder soberano e a vida nua I. Belo Horizonte: Editora UFMG; 2002.

11. Lima EC. A onomástica Katukina é Pano? Rev Antropol (São Paulo) 1997; 40:7-30.

12. Erikson P. Les Matis d'Amazonie. Parure des corps, identité ethnique et organisation sociale [Doctoral Dissertation]. Paris: University of Paris X - Nanterre; 1990.

13. Aristotle. Politika. Livro quarto. São Paulo: Martin Claret; 2005.
14. Rohden F. A arte de enganar a natureza: contracepção, aborto e infanticídio no início do século XX. Rio de Janeiro: Editora Fiocruz; 2003.

15. Tooley M. Abortion and infanticide. Oxford: Oxford University Press; 1983.

16. Aldeia. Infanticídio nos U.S.A. http://aborto.aald eia.net/infanticidionosusa.htm (accessed on 15/ Oct/2006).

17. Agência EFE. Igreja Anglicana aceita eutanásia em bebês muito doentes. http://noticias.terra.com. $\mathrm{br} /$ ciencia/interna/0,,OI1244047-EI238,00.html (accessed on 12/Nov/2006).

18. Garrafa V, Porto D. Intervention bioethics: a proposal for peripheral countries in a context of power and injustice. Bioethics 2003; 17:399-416.

19. Oliveira RC. O trabalho do antropólogo. São Paulo: Editora Unesp; 1998.

20. Ramos AR. Os direitos do índio no Brasil: na encruzilhada da cidadania. Brasília: Universidade de Brasília; 1991. (Série Antropologia, 116).

21. Habermas J. Consciência moral e agir comunicativo. Rio de Janeiro: Tempo Brasileiro; 1989.

22. Santos BS, organizador. Conhecimento prudente para uma vida decente: um discurso sobre as ciências revisitado. São Paulo: Cortez Editora; 2004.

23. Olivé L. Epistemologia na ética e nas éticas aplicadas. In: Garrafa V, Kottow M, Saada A, organizadores. Bases conceituais da bioética: enfoque latino-americano. São Paulo: Gaia/Organização das Nações Unidas para a Educação, a Ciência e a Cultura; 2006. p. 121-39.

24. Freitas FO, Freitas JZF, Alves J. Albinismo em comunidades indígenas: o fator cultural afetando a prevalência da doença. http://sis.funasa.gov.br/ portal/publicacoes/pub905.pdf (accessed on 23/ May/2006).

Submitted on 04/May/2009

Approved on 11/May/2009 